\title{
Avifaunal inventory of northern Entre Ríos, Argentina: noteworthy records and conservation prospects
}

\author{
Sebastián DARDANELLI ${ }^{1}$, C. Fabricio REALES ${ }^{2} \&$ Juan Andrés SARQUIS ${ }^{3}$
}

\begin{abstract}
${ }^{1}$ Instituto Nacional de Tecnología Agropecuaria (INTA), Estación Experimental Agropecuaria Paraná, Ruta 11, km 12.7, Oro Verde, Entre Ríos, Argentina; dardanelli.sebastian@inta.gob.ar. ${ }^{2}$ Centro de Investigaciones Científicas y Transferencia de Tecnología a la Producción (CICyTTP - CONICET - Prov. Entre Ríos - UADER), Matteri y España, Diamante, Entre Ríos, (Argentina). ${ }^{3}$ Instituto Nacional de Limnología (CONICET-UNL). Ciudad Universitaria, Santa Fe, Argentina.
\end{abstract}

\begin{abstract}
Biodiversity inventories remain fundamental tools for biodiversity conservation. Neotropical biota has poor faunal inventories. In Argentina, the avifauna of the province of Entre Ríos is still not well known. Here, we present the first exhaustive bird inventory of Northern Entre Ríos. We recorded 317 bird species. Three species were new for the province of Entre Ríos, and eight were new for Northern Entre Ríos. We recorded 17 threatened species, 4 biome-restricted species and two restricted range species. The high bird diversity of Northern Entre Ríos contrasts with the lack of effective reserves to ensure the survival of endangered species. Creation of natural reserves in this area is urgent. These protected areas should have a management plan and stable park rangers assigned, to ensure the protection of the avian diversity of Northern Entre Ríos.
\end{abstract}

Key words: Birds, biodiversity; conservation; endangered species; IBAs

Resumen: Inventario de avifauna del norte de Entre Ríos, Argentina: registros notables y perspectivas de conservación. Los inventarios de Biodiversidad siguen siendo herramientas fundamentales para la conservación de la biodiversidad. La biota neotropical posee inventarios incompletos de fauna. En Argentina, la avifauna de la provincia de Entre Ríos permanece poco estudiada. Presentamos el primer inventario exhaustivo de aves para el norte de Entre Ríos. Registramos 317 especies de aves, tres son nuevas para la provincia de Entre Ríos y ocho son nuevas para el norte de Entre Ríos. Diecisiete especies están consideradas amenazadas, 4 son especies restringidas a un bioma y dos especies son de rango restringido. La alta diversidad de aves del norte de Entre Ríos contrasta con la falta de reservas efectivas que puedan asegurar la supervivencia de las especies amenazadas. La creación de reservas naturales en esta región es urgente. Estas áreas protegidas deberían tener planes de manejo y guardaparques estables asignados, para asegurar la protección de la diversidad de aves del norte de Entre Ríos.

Palabras clave: Aves; biodiversidad; conservación; especies amenazadas; AICAs

\section{INTRODUCTION}

Biodiversity inventories and species distribution maps remain fundamental tools for biodiversity conservation at different scales (Norris $\&$ Pain, 2002). The Neotropical region possesses poor faunal inventories and areas with lack of empirical data (Arzamendia \& Giraudo, 2004; Bini et al., 2006). In Argentina, in areas like Entre Ríos province, knowledge about terrestrial vertebrates remains insufficient (Arzamendia \& Giraudo, 2004; Arzamendia \& Giraudo, 2012; Berduc et al., 2010).

Freiberg (1943), De la Peña $(1996 ; 1997 ; 2012)$ and Beltzer et al. (2006) made some avifaunal inventories of the Entre Ríos province. In spite of that, Entre Ríos avifauna is still not well known, and taxonomic, ecological and biogeographic works continue to add new species for the province (Aceñolaza et al.; 2004; Bodrati \& Sierra, 2009; Alvarado \& La Grotteria, 2011; Passafaro, 2012; Cantador, 2014; Sarquis et al., 2017).

Freiberg (1943) listed 301 species of birds for Entre Ríos. Afterwards, de la Peña (1997) mentioned 333 species, although the same author indicated 261 species 15 years later, considering only empirical data (de la Peña, 2012). On the other hand, Beltzer et al. (2006) found 291 species in the province. Consequently, the total number of bird species in Entre Ríos is still uncertain. Within the province, the north is characterized as being the least studied area, and there are 
few publications reporting new species for this region (Grassini \& Bonomi, 2013; Reales et al., 2015). Moreover, Freiberg (1943) indicated that the north of the province has a high diversity of birds, which has not yet been thoroughly explored. As it has received little attention by ornithologists, the value of this region for avian conservation has not been assessed. There is an IBA, AR 127 "Selva de Montiel" designated by Birdlife International (2017a) covering a small portion of the study area (3.2\%). However, the selection and delimitation of this area was established based on experts opinion and is not supported by empirical data or scientific studies. Protected areas in the region are lacking and although there are some private reserves, there is no effective protection in the area.

In this study, we present the first exhaustive avian inventory of the North of the province of Entre Ríos, an area with high biodiversity but insufficiently studied. Additionally, we analyzed species of importance and its relevance for the conservation of biodiversity.

\section{METHODS}

\section{Study area}

Northern Entre Ríos is located in eastern Argentina, Between $30^{\circ} 10^{\prime}$ and $31^{\circ} 28^{\prime} \mathrm{S}, 57^{\circ} 49^{\prime}$ and $59^{\circ} 57^{\prime} \mathrm{W}$, we specifically covered the area of four Departments, La Paz, Feliciano, Federal and Federación (Fig. 1). The total area was $21722 \mathrm{~km}^{2}$, with elevations ranging from 15 to $90 \mathrm{~m}$ a.s.l.

The climate of the region is variable, from north to south, from wet subtropical to wet temperate, mean annual rainfall varies between 1000 y $1200 \mathrm{~mm}$, mean annual temperature between 18 to $20^{\circ} \mathrm{C}$ (Menéndez \& La Rocca, 2007; Morello et al., 2012). For analysis of data in a biogeographic context the area was subdivided into three ecoregions following the last updated classification for Argentina (Morello et al., 2012):

1- Delta and Islands of Paraná and Uruguay Rivers: located on the margins of Paraná and Uruguay rivers. On the West and East of the study area (Fig. 1). It comprises about $5.7 \%$ of the study area. Vegetation types include riparian forest, grasslands and aquatic vegetation characteristic of wetlands. It also includes many islands of different sizes.

2- Iberá: located in the extreme northwest it comprises only $2.3 \%$ of the study area (Fig 1 ). Vegetation types include aquatic vegetation characteristic of wetlands, and partially inundated riparian forest, open xerophytic savannas, and xerophytic woodlands.

3- Espinal: comprises most of the study area, about $92 \%$ (Fig. 1). It is the dominant ecoregion. Vegetation types include low xerophytic woodlands and savannas, 6 to $12 \mathrm{~m}$ tall, dominated by mesquite trees (Prosopis spp.) and palm trees (Trithrinax campestris).

\section{Sampling}

We carried out an avifaunal inventory in different localities covering the North of Entre Ríos (Fig. 1) from December 2014 to January 2018. Systematic sampling of birds consisted of five different methods: transects, unlimited distance point counts, mist netting, Mackinnon lists and opportunistic observations (Bibby et al., 2000). Total field sampling effort was 812 hours and 55720 individuals detected. We supported species records with observations, sound recordings, specimens, and/or photographs. The information was supplemented with georeferenced records from the scientific literature with vouchers or photographs (e.g. Freiberg, 1943; Berduc, 1997; Beltzer et al., 2006; Casañas et al., 2007; de la Peña et al., 2009; de la Peña, 2012; Grassini \& Bonomi, 2013; Reales et al., 2015; Sarquis et al., 2017). We used field guides and taxonomic keys to identify species (Olrog, 1968; Olrog, 1979; Rodríguez Mata et al., 2006; Narosky \& Yzurieta, 2010). We employed external morphological characters such as the colour of different body parts to compare and determine species. Moreover, we obtained information from revision of natural history museums georeferenced specimens (c. 210 hours reviewing) of the following museums: Museo de Entre Ríos (MER - Entre Ríos, Argentina ), Museo Provincial de Ciencias Naturales Florentino Ameghino (MFA - Santa Fe, Argentina), Museo Argentino de Ciencias Naturales (MACN - Buenos Aires, Argentina), Museo de la Fundación Félix de Azara (CFA - Buenos Aires, Argentina), Museo de La Plata (MLP - La Plata, Argentina), Museo de Ciencias Naturales, Fundación Miguel Lillo (FML - Tucumán, Argentina), Museo de la Facultad de Ciencias, Universidad de la República (FCRU - Montevideo, Uruguay), and Museo de Historia Natural (MNHN - Montevideo, Uruguay). We obtained some extra information from known web-based databases like eBird (http://ebird/content/Argentina) and Ecoregistros (www.ecoregistros.org), with supporting evidence like photographs, voice recordings or videos of georeferenced specimens (c. 100 hours reviewing databases). We analyzed 

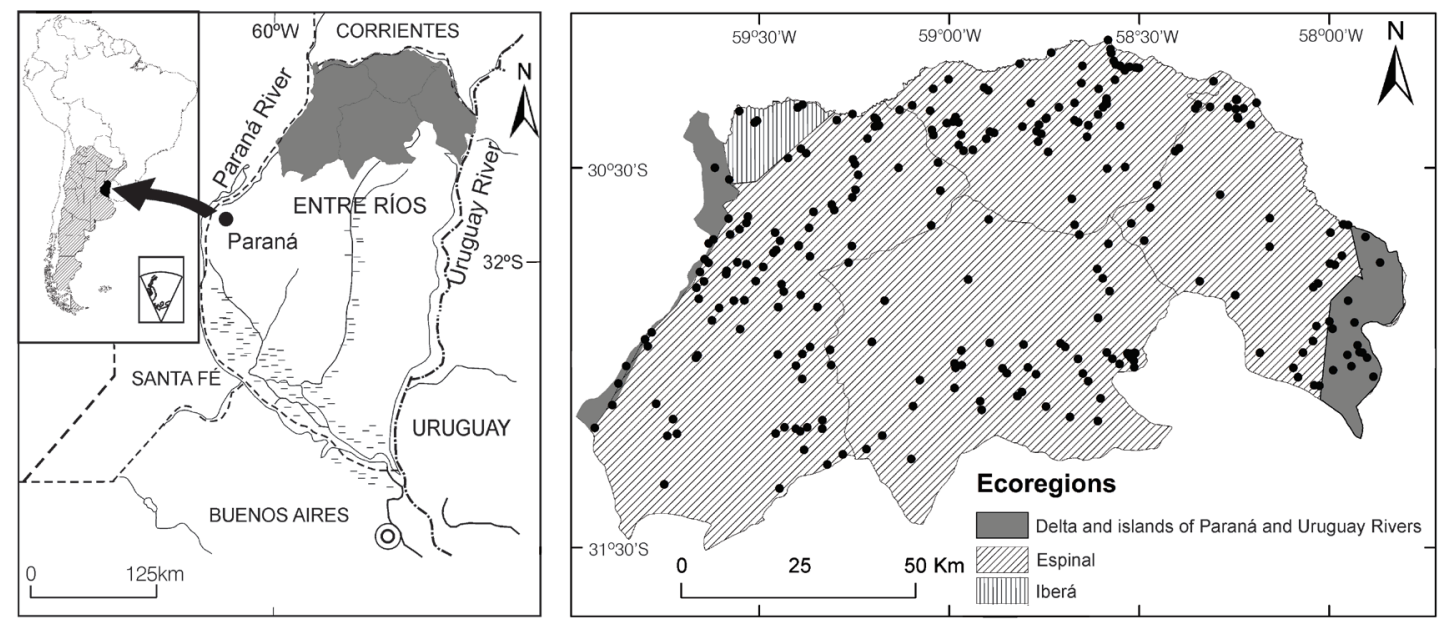

Fig. 1. Map of the study area in northern Entre Ríos, Argentina. Black dots represent field-sampling sites.

information not collected directly by us on the field very carefully, to avoid including dubious uncertain data.

We classified the abundance of the species as follows:

i. $\quad$ Abundant $=$ recorded in $100 \%$ of the samples in large numbers, in suitable environment

ii. $\quad$ Common $=$ recorded in $91-100 \%$ of samples; in a suitable environment

iii. Frequent $=$ recorded between $30-90 \%$ of samples, in a suitable environment

iv. $\quad$ Scarce $=$ recorded between $10-29 \%$ of samples, in a suitable environment

v. $\quad$ rare $=$ recorded between $2-9 \%$ of samples, in a suitable environment

vi. Occasional $=$ recorded in less than $2 \%$ of samples.

For taxonomy and nomenclature, we followed SACC (Remsen et al., 2018). Global conservation status follows IUCN-Birdlife International (Birdlife International, 2017b) and national conservation status follows "Categorización de las Aves de Argentina" (Ministerio de Ambiente y Desarrollo Sustentable \& Aves Argentinas, 2017).

\section{RESULTS}

We recorded 317 bird species (Appendix) belonging to 55 families and 23 orders. One hundred and fifty-eight of the species were passerines and
159 were non-passerines. Three were exotic invasive species, Acridotheres cristatellus, Columba livia and Passer domesticus, the latter 2 are naturalized species in Argentina, very common around urban and rural houses. The most numerous family was Tyrannidae with 35 species, followed by Traupidae with 34, Furnaridae with 27 and Accipitridae with 19 species (Fig. 2).

Eleven of the recorded species were distributional novelties. Eight species were new for Northern Entre Ríos: Anas cyanoptera, Polytmus guainumbi, Theristicus caudatus, Asio clamator, Polystictus pectoralis, Phylloscartes ventralis, Myiarchus tyrannulus, and Catharus ustulatus; and three were new species for the province of Entre Ríos: Sarcoramphus papa, Ictinia mississippiensis and Casiornis rufus.

Some of the species recorded were of conservation concern because of being biome-restricted, restricted range or threatened. We found four biome-restricted species, Cranioleuca sulphurifera, Spartonoica maluroides, Sporophila palustris and $S$. cinnamomea; the latter two species being also restricted range species (Birdlife International 2017b). In addition, we registered 17 endangered species at the national level (Appendix): Rhea americana, Cairina moschata, Sarkidiornis melanotos, Polytmus guainumbi, Bartramia longicauda, Calidris subruficollis, Spartonoica maluroides, Polystictus pectoralis, Sporophila hypoxantha, S. ruficollis, S. palustris, S. hypochroma, S. cinnamomea, Emberizoides ypiranganus, Gubernatrix cristata, Cyanoloxia glaucocaerulea, and Amblyramphus holosericeus. Nine of these species are also threatened at the 


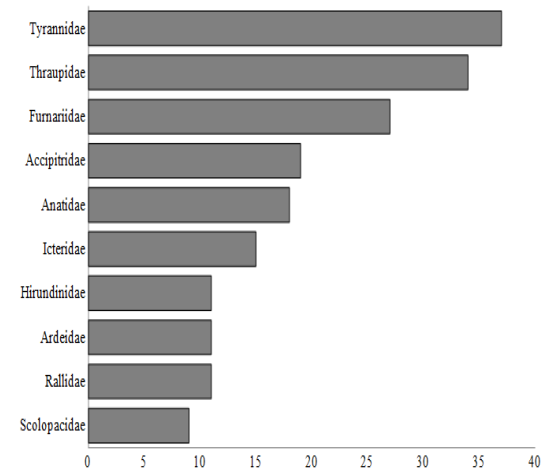

Fig. 2. Species richness by family for the 10 most abundant families recorded in northern Entre Ríos, Argentina.

international level (Appendix): R. americana, C. subruficollis, S. maluroides, P. pectoralis, $S$. ruficollis, S. palustris, S. hypochroma, S. cinnamomea, and G. cristata.

\section{Noteworthy conservation and biogeogra- phic records}

The following is an annotated list of species of interest for conservation or records that represent a distributional or biogeographic novelty for the region.

\section{Rhea americana (Greater Rhea)}

This species presents more than 180 records from 1922 to 2017 in Northern Entre Ríos. Is a scarce species in the region, distributed in xerophytic woodlands, grasslands and agro-ecosystems. Is categorized as Near-threatened at the national (Ministerio de Ambiente y Desarrollo Sustentable \& Aves Argentinas, 2017) and international level (Birdlife International, 2017b).

\section{Cairina moschata (Muscovy duck)}

From 1924 to 2017, presents more than 25 records, most of them from the suited area. It is a rare species in Northern Entre Rios wetlands. It is probable that this species is more common in Entre Ríos that it seems, but it remains undetected. Is listed as vulnerable in Argentina (Ministerio de Ambiente y Desarrollo Sustentable \& Aves Argentinas, 2017).

\section{Sarkidiornis melanotos (Comb duck)}

From 1924 to 2017, presents eight records for the province, but only two in the North, at Tacuaras district and Río Guayquiraró, both in $\mathrm{La} \mathrm{Paz}$ department, northwest of the study area. More recently, it was photographed on 02/08/2016 in the same area (Navarro, 2016b). This duck is occasional in Entre Ríos in wetlands nearby the Paraná River. This species is listed as vulnerable at the national level (Ministerio de Ambiente y Desarrollo Sustentable \& Aves Argentinas, 2017).

\section{Anas cyanoptera (Cinnamon Teal)}

We recorded three individuals recorded on 14 November 2015 at Las Tunas stream, Federación department, in the north of the study area. We observed another individual the following day near San Jaime de la Frontera town, $40 \mathrm{~km}$ northeast from the previous record, in Federación department. Those are the first records of this species for Northern Entre Ríos. The few previous records for this species in the province belong to southerly locations (Beltzer et al., 2006; de la Peña, 2012).

\section{Crotophaga major (Greater Ani)}

On 15 February 2015, one individual was photographed at Don Sebastián Private Reserve, in La Paz department, northwest of the study area (eBird, 2012). This is the first record of this species for Northern Entre Ríos. This species had two previous records along the Uruguay River (De la Peña \& Rumboll, 1998) and one in the Paraná River (Beltzer, 2006) in the Pre-Delta National Park. The presence of this species in more southerly latitudes of the province is due to the importance of the Paraná and Uruguay rivers as biological corridors, as was demonstrated by other authors (Nores et al., 2005; Berduc et al., 2015).

\section{Polytmus guainumbi (White-tailed Golden- throat)}

We recorded one individual on 25 November 2016 near Las Mulitas in La Paz department, northwest of the study area. This is the first record of this species for Northern Entre Ríos. The only previous record of this species for the province was one further south, at Paraná city (Rovira \& Beltzer, 1992). The records of this species are associated with the Paraná River and secondary streams. It is probable that $P$. guainumbi is a bird that uses the rivers as corridors, as proposed by other authors for birds at Uruguay and Paraná rivers (Nores et al., 2005; Berduc et al., 2015). This species is listed as Near-threatened 
in Argentina (Ministerio de Ambiente y Desarrollo Sustentable \& Aves Argentinas, 2017).

\section{Anthracothorax nigricollis (Black-throated Mango)}

We recorded this species on 18 March 2017, at Estancia Tunas Corá, Feliciano department (Fig. 3 ). This is the first record for the study area. It was previously recorded for southerly locations, on riparian forest along the Uruguay River on eastern Entre Ríos (de la Peña, 2012).

\section{Theristicus caudatus (Buff-necked Ibis)}

This species presents only one record with a photograph on 18 June 2016 (Navarro 2016a), near Arroyo Moreyra in Federal department, south of the study area. This is the first record for the study area. Theristicus caudatus was originally conspecific with $T$. melanopis and later as a separate species, but still, no explicit rationale has been published (Remsen et al., 2018 and references therein).

\section{Sarcoramphus papa (King Vulture)}

It is a new species for the province of Entre Rios. We recorded one individual on 23 November 2016, at the center of the study area in Distrito Chañar, Feliciano Department (-30.266405 ${ }^{\circ}$ $58.949837^{\circ}$ ). The individual was flying high and doing circles with two individuals of Cathartes aura and one individual of Ciconia maguari. It was identified by; its bare neck and head and caruncle bright orange, the white plumage of the body, with flight feathers black, as is collar and tail. The North of Entre Ríos represents the south of it is distribution and the species is probably occasional or vagrant there (Olrog, 1968; Narosky \& Yzurieta, 2010). It would be necessary to confirm with voucher or photography the presence of this species in Entre Ríos.

\section{Ictinia mississippiensis (Mississippi Kite)}

It is a new species for the province of Entre Rios. One individual photographed on 15 of February 2015 (eBird, 2012). Later on, 01/03/2015, a flock of 27 individuals photographed (eBird, 2012). All records at Don Sebastián Private reserve in La Paz Department, northwest of the region. They constitute the southernmost records of the species.

\section{Bartramia longicauda (Upland Sandpiper)}

This species presents 24 records for Entre Ríos between 1939 and 2017 (1939 specimen collected in MACN 5221, de la Peña, 1996; 2012; de la Peña et al., 2009). The distribution of this species comprises the whole province. However, it only presents two records for the north in Chajarí and Santa Ana, both from Federación department. In spite of this, the agricultural advance modified the landscape of a large part of the south and the center of the province (Thompson et al., 2013), giving greater relevance in terms of conservation to the north of the province. This species is listed as Near-threatened in Argentina (Ministerio de Ambiente y Desarrollo Sustentable \& Aves Argentinas, 2017).

Calidris subruficollis (Buff-breasted Sandpiper)

There are 16 records for the province since 1989. All records are associated with the "Delta and Islands of the Paraná and Uruguay Rivers" ecoregion. Globally it is listed as Near-threatened (Birdlife International, 2017b), but in Argentina is listed as Vulnerable (Ministerio de Ambiente y Desarrollo Sustentable \& Aves Argentinas, 2017). This species breeds on well-drained soils in the tundra, on sites with tussocks and scant vegetation (Birdlife International, 2017b). During migration, it occurs on many short grass habitats (Norling et al., 2012). Recently, conservation actions are underway in Argentina (Birdlife International, 2017b), and could be developed in Buenos Aires and Entre Ríos provinces, which still have important habitat for this species.

\section{Asio clamator (Striped Owl)}

We recorded two individuals on 2 April 2016 at Federal department south of study area. Another two individuals recorded on 24 November 2016, at Feliciano department, north of study area. There are only two other previous records for the North of Entre Ríos, one for La Paz department in 1979 (Beltzer, 1981) and another for Federación Department in 2013 (Grassini, 2013). There are 17 more records for southerly locations in Entre Ríos province (Freiberg, 1943; Beltzer et al., 2006; de la Peña, 2012). 


\section{Psittacara leucophthalmus (White-eyed Pa- rakeet)}

One individual observed dead after crashing with a car on 21 April 2017, in the south-west of the study area, near Alcaraz stream at southern La Paz Department (-31.161269; $\left.-59.726856^{\circ}\right)$. The specimen is located at CICyTTP-CONICETUADER (CICYTTP-ZV-APS-22) (Fig. 3). Occasional for the region and the province. This parrot presents two previous records in the north of Entre Ríos and eight for southerly locations in the rest of the province. The first record for the north come from Arroyo Hondo, La Paz Department on May 1926 and presents a specimen deposited in Museo de Entre Ríos (MER - Or-1164). The other records are located in San Victor, Feliciano Department from 1991(de la Peña, 1996; de la Peña, 2012).

\section{Polystictus pectoralis (Bearded Tachuri)}

P. pectoralis presents more than 50 records in the province since 1954, but only one record with a photograph on 30 January 2016, in the North from private Natural reserve "El Ceibo" in Federación department (Caprotti, 2016). This is the first record of this species for Northern Entre Ríos. The Bearded Tachuri is listed as Nearthreatened in Argentina and Globally (Ministerio de Ambiente y Desarrollo Sustentable \& Aves Argentinas, 2017; Birdlife International, 2017b).

\section{Phylloscartes ventralis (Mottle-cheeked Tyran- nulet)}

We observed one individual on 22 September 2016, in the riparian Forest of Gualeguay River, near Nueva Vizcaya, in the Federal department, south of the study area. This is the first record of this species for Northern Entre Ríos. This species had 32 previous records for Entre Rios, out of the study area (Alonso, 2008; Marateo et al., 2009; de la Peña, 1996; 2012). The presence of this species in more southerly latitudes in Entre Ríos is always associated to the riparian forest of the Paraná and Uruguay rivers as proposed by other authors (Nores et al., 2005; Berduc et al., 2015).

\section{Casiornis rufus (Rufous Casiornis)}

One individual recorded with a photograph on 24 May 2014 (Savor, 2014). Five individuals recorded on 10 October 2015 in different areas of Don Sebastián Private Reserve, in La Paz Department, northwest of the study area (Appendix). There are no published records of this species for northern Entre Ríos (see Freiberg, 1943; De La Peña \& Rumboll, 1998; Beltzer et al., 2006; Narosky \& Yzurieta, 2010). We concluded that the records from the south should not be considered as the first ones because no solid evidence is provided. Records presented here in the North are the first records of the species for the province of Entre Ríos.

\section{Myiarchus tyrannulus (Brown-crested Flycat- cher)}

First record for Northern Entre Ríos. One individual recorded on 17 September 2015 and two on 19 September 2015, both records at Don Sebastián Private reserve in La Paz Department, northwest of the region. Later we recorded one individual at Feliciano department, north of the study area in xerophytic Espinal woodland. For the rest of the province, it presents records in Concordia (specimen at MLP 8098), in Pre-Delta National Park (Alonso \& Ronchi-Virgolini, 2008) and at Perdices (eBird, 2012).

\section{Catharus ustulatus swainsoni (Swainson's Thrush)}

We captured one individual Swainson's Thrush on a mist net (12x25.5 m, $36 \mathrm{~mm}$ mesh) on 15 November 2016 (Fig. 3), in xerophytic Woodland on the Espinal ecoregion, in the center of the study area, at Federal Department. This is the first record for the study area. For the rest of the province, this species has only one record in 1989 (Parera, 1990) on riparian forests of the coast of Parana River, $200 \mathrm{~km}$ to the southwest. This is the second record for the province after 27 years, and the first documented with a photograph. C. u. swainsoni is a migrant that breeds in Canada and Northern USA and winters in western South America, including humid forests in northwestern Argentina (del Hoyo \& Collar, 2018).

\section{Seedeaters of the Genus Sporophila}

Entre Ríos is located between subtropical and temperate areas of South America and has a wide variety of habitats ranging from different types of wetlands to pastures, savannas and forests (Giarla \& Jansa, 2014) that represent good habitats for this genus. As a consequence, this genus has 

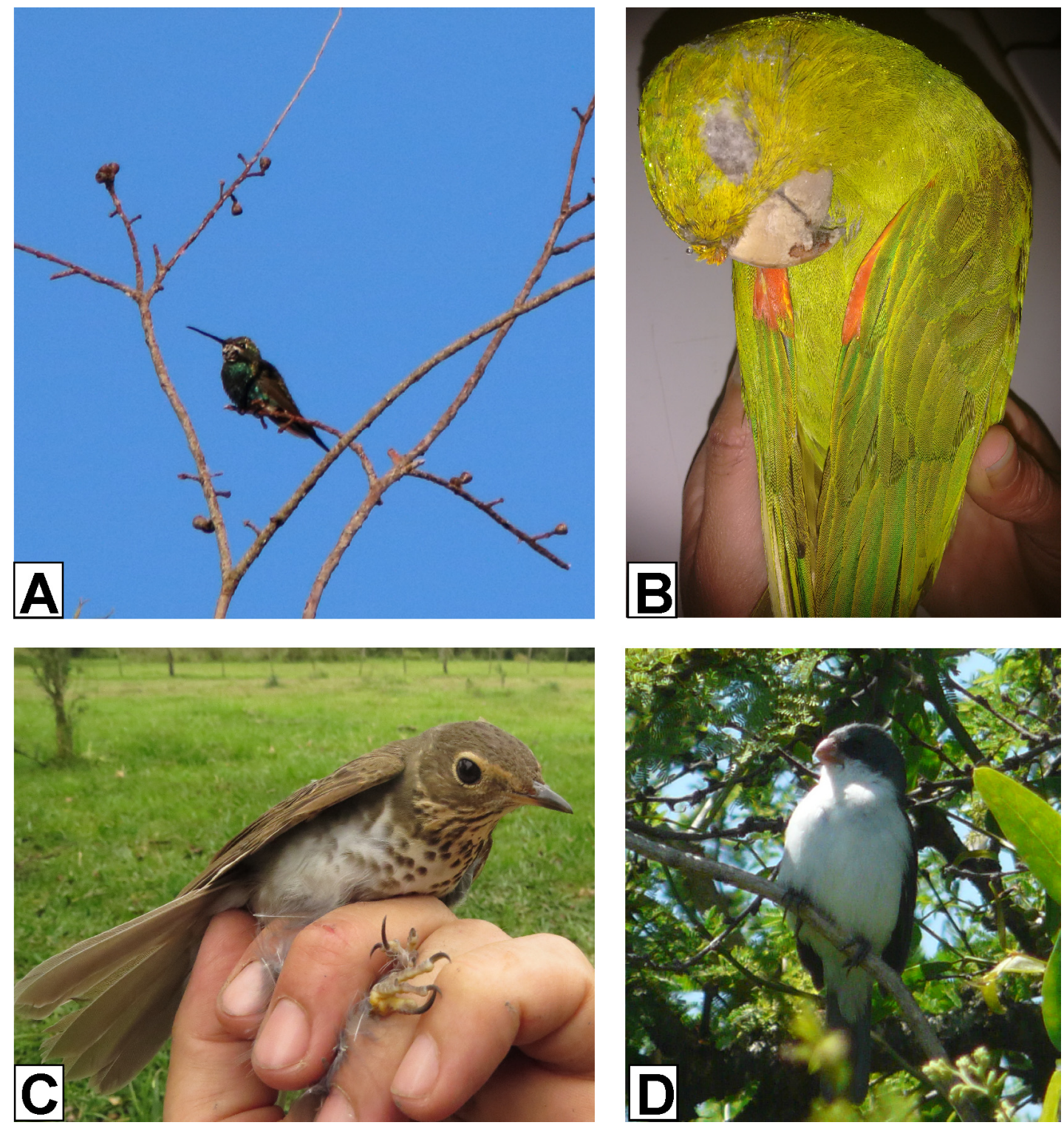

Fig. 3. Four noteworthy bird species recorded in northern Entre Ríos, Argentina. A: Juvenile male of Blackthroated Mango (Anthracothorax nigricollis). B: White-eyed Parakeet (Psittacara leucophthalmus). C: Swainson's Thrush (Catharus ustulatus swainsonii. D: White-bellied Seedeater (Sporophila leucoptera).

a great diversity of species in the province where is possible to find eight species: $S$. hypoxantha, S. ruficollis, S. palustris, S. hypochroma, S. cinnamomea, $S$ collaris, $S$. caerulescens and $S$. leucoptera. Generally, they inhabit in grasslands and wetlands. Five of these species $(63 \%)$ are considered threatened in Argentina (Ministerio de Ambiente y Desarrollo Sustentable \& Aves Argentinas, 2017) and/or globally (Birdlife International, 2017b). Accordingly, S. hypoxantha is listed as Near-threatened in Argentina; S. ruficollis is Near-threatened in Argentina and globally; S. hypochroma is globally Near-threatened and Vulnerable in Argentina and; S. cinnamomea is listed as Vulnerable globally and nationally, and S. palustris is listed as Endangered both globally and nationally. Seedeaters have been affected mainly by changes in land use in the last decades in Entre Ríos (Thompson et al., 2013). 
White-bellied Seedeater (S. leucoptera) is not threatened but is a recent addition for Entre Ríos avifauna, was first recorded for Entre Ríos by Alfredo Berduc on 1996, at Curuzú Chalí Island, in the Paraná river, extreme northwest of the study area (Sarquis et al., 2017). More recently, one individual was observed and photographed in a xerophytic Espinal woodland patch nearby a wetland (Fig. 3) on 21 October 2015, also in the northwest of the study area $\left(-30.336958^{\circ}\right.$, $-59.356429^{\circ}$ ), near Paso Telégrafo at La Paz department. We confirm $S$. leucoptera as a new species for the province.

\section{Emberizoides ypiranganus (Lesser Grass-Finch)}

Presents three records for the north of Entre Ríos in Federación department, and three more for southerly locations outside the study area along the Uruguay River in the east of Entre Ríos (de la Peña, 2012). This species inhabits in grasslands and wetlands and is listed as Near-threatened in Argentina (Ministerio de Ambiente y Desarrollo Sustentable \& Aves Argentinas, 2017).

\section{Thlypopsis sordida (Orange-headed Tanager)}

Seven individuals recorded by Alfredo Berduc in December 1996 at Curuzú Chalí Island, in the Paraná River, on the riparian forest on the extreme northwest of the study area (Berduc, 1997). T. sordida has six more records, further south, out of the study area; all associated with riparian forests of the rivers Parana and Uruguay (de la Peña, 2012).

\section{Gubernatrix cristata (Yellow Cardinal)}

This is one of the most endangered land birds in Argentina. It is considered as both nationally and globally endangered (Ministerio de Ambiente y Desarrollo Sustentable \& Aves Argentinas, 2017; Birdlife International, 2017b). This emblematic species presents more than 75 records for the province, since 1914. At present, the last populations in Entre Ríos persist in the Espinal at the North of the province (Ortiz, 2008). It is fundamental to create reserves for the conservation and management of this species.

Cyanoloxia glaucocaerulea (Glaucous-blue Grosbeak)

This species presents only two records for the north of Entre Ríos, both associated to the Paraná and Uruguay River, at La Paz and Federación departments (Beltzer et al., 2006; de la Peña, 2012). For southerly locations, it presents
20 records in the province since 1926 (Smyth, 1928; Beltzer et al., 2006; de la Peña, 2012). C. glaucocaerulea inhabits in riparian forests and is considered as Near-threatened in Argentina (Ministerio de Ambiente y Desarrollo Sustentable \& Aves Argentinas, 2017).

\section{Amblyramphus holosericeus (Scarlet-headed Blackbird)}

This species presents only four records for the north of Entre Ríos in La Paz and Federación departments (Beltzer et al., 2006; de la Peña, 2012). Scarlet-headed Blackbird is considered as Near-threatened in Argentina (Ministerio de Ambiente y DesarrolloSustentable \& Aves Argentinas, 2017).

\section{Identification mistakes and old records of species already extinct}

There are some species mentioned in the literature that we consider identification mistakes or old records of species already extinct in the study area. The IUCN (2001) says that "presumes that a taxon is extinct when exhaustive surveys of its habitats, known or expected, at the appropriate times (daily, seasonal, annual), and throughout its historical distribution, has not been able to detect a single individual". We identified two species that can be considered extinct at the regional level. One of these species is Sturnella defilippii, for which there have been no records since 1923 when the last individual of this species was recorded by Serié and Smith (1923). For southerly locations in the rest of the province, it was last recorded 42 years ago by Zapata (1975) in the southeast of Entre Ríos. This author indicated that this bird was one the three icterids observed in the area. Notably, the author did not record Sturnella superciliaris, which is a common species in this area. It is very probable that this was a misidentification by this author. Despite this last record, it should be considered extinct for the north of Entre Ríos. The other species is Cariama cristata, which was recorded by Serié and Smyth (1923) and Smyth (1928) in Santa Elena, La Paz department. Those are the only records of this species for the North of Entre Ríos. This species is easily recognizable by its large size and characteristic appearance (Olrog, 1968; De La Peña \& Rumboll, 1998; Narosky \& Yzurieta, 2010). In spite of that, there are no records in the last 95 years and may have gone extinct at the regional level.

At the same time, we found two species in the 
literature that are probably result of identification mistakes. Xanthopsar flavus presents only one record for the north of Entre Rios, detected by Serié and Smith (1923) in Santa Elena, La Paz department. Contrarily, there is no verifiable evidence that the species can inhabit the Paraná River since its confirmed distribution includes the south of Misiones, northeast of Corrientes, southeast of Entre Ríos and Buenos Aires (Fraga, 2008; Fandiño \& Giraudo, 2012). Furthermore, Serié and Smyth (1923) recorded Glaucidium nana in Santa Elena, La Paz department 95 years ago but never cited Glaucidium brasilianum, a common and similar species in Entre Rios. G. nana breeds in temperate forest and surrounding environments in western Patagonia. In autumn it migrates northwards (Narosky \& Yzurieta, 2010), being an occasional migrant in central Argentina (Holt et al., 2018).

\section{DISCUSSION}

Our study reported more species for less than a quarter $(23 \%)$ of the surface of Entre Ríos than the previous studies for the whole province (see Freiberg, 1943; Beltzer et al., 2006; de la Peña, 2012). These results reaffirm the idea that the north of Entre Ríos is a sub-studied region in relation to its avifauna, being a common situation in the areas of the Neotropical region (Bini et al., 2006). This underestimation of its biodiversity makes it difficult to plan conservation actions to protect the regional avifauna, being necessary to know species distribution to make better conservation planning (Myers et al., 2000). Northern Entre Ríos is an area of high diversity of birds in Argentina. However, no government actions have been implemented to transform prioritized areas like "Selva de Montiel" IBA, and nearby zones into effective protected areas. According to our results, monitoring programs in the suited area would help to assess the status of bird populations, and probably the designation of protected areas. Such information will be fundamental in establishing more precise and systematic baselines for biodiversity management and conservation at regional scales.

We reported 17 threatened species at the national level and 9 species globally threatened for the study area. We also reported four biomerestricted species and two restricted range species. Consequently, this region together with the southeast of the province, are the most important areas for the conservation of birds in the province of Entre Ríos. By comparison, the southeast already has four IBAs delimited, probably because of being near to Buenos Aires city, which has the highest density of ornithologist and birdwatchers in Argentina. Fandiño \& Giraudo (2012) described a similar pattern for the neighbouring province of Santa Fe, where there is an overestimation of avifaunal richness near big cities with high density of ornithologists and an underestimation of bird diversity in other less sampled areas. Consequently, Northern Entre Ríos has only one IBA (area of importance for birds) recognized by Birdlife International ("AR 127” see Birdlife International, 2017a).

There are some protected areas in northern Entre Ríos, a multiple-use provincial reserve "Selva de Montiel" of about 70,000 ha (in private lands), and around eight private reserves totalling nearly 9600 ha. However, none of these reserves has park rangers, so they have no control on terrain and depend on the conservationist will of landowners. It would be very important to have effective reserves, with the presence of park rangers and management plans, to ensure the survival of the 17 species of conservation concern that depend on these natural environments. It is worth mentioning that two of the three ecoregions represented in the study area, Delta and islands of the Paraná and Uruguay rivers and the Espinal, are the most unprotected nationwide (sensu Brown et al., 2005). We strongly recommend the creation of effective reserves to protect the remaining natural environments and the valuable biodiversity of northern Entre Ríos.

Appendix: can be found as supplementary file online at http://revista.macn.gob.ar/ojs/index. $\mathrm{php} /$ RevMus/rt/suppFiles/....

\section{ACKNOWLEDGMENTS}

CFR and JAS benefited from PhD fellowships from the Consejo Nacional de Investigaciones Científcas y Técnicas (CONICET). Funding for this study was provided by The Birdfair/ RSPB Research Fund for Endangered Birds, NBC- Neotropical Bird Club Conservation, INTA Project PNNAT 1128053, Fontagro FTG/ RF-15461-RG, CONICET (PIP 2011-0355) and laboratory of biogeography and conservation of terrestrial tetrapods INALI-CONICET-UNL). We thank private landowners who allowed us to stay and survey birds in their properties. 


\section{REFERENCES}

Aceñolaza, P.G., H.E. Povedano, A.S. Manzano, J.D. Muñoz, J.I. Areta, \& A.L. Ronchi-Virgolini. 2004. Biodiversidad del Parque Nacional Pre-Delta. Insugeo, Miscelánea, 12(1), 169-184.

Alonso, J.M. \& A.L. Ronchi-Virgolini. 2008. Avifauna del Parque Nacional Pre-Delta, Entre Ríos, Argentina. Cotinga, 29(1), 126-134.

Alvarado, H. \& J. La Grotteria. 2011. Expansión del Picapalo Colorado (Campylorhamphus trochilirostris) hasta el límite austral del bosque en galería sobre el Río Paraná en la provincia de Entre Ríos. EcoRegistros Revista, 1(1), 1-4.

Arzamendia, V. \& A.R. Giraudo. 2004. Usando patrones de biodiversidad para la evaluación y diseño de áreas protegidas: las serpientes de la provincia de Santa Fe (Argentina) como ejemplo. Revista Chilena de Historia Natural, 77(2), 335-348.

Arzamendia, V. \& A.R. Giraudo. 2012. A panbiogeographical model to prioritize areas for conservation along large rivers. Diversity and Distributions, $18(2), 168-179$.

Beltzer, A., P.A. Collins \& M.A. Quiroga. 2006. Atlas ornitogeográfico de la provincia de Entre Ríos. Santa Fe: Asociación de Ciencias Naturales del Litoral.

Beltzer, A.H. 1981. Lista preliminar de las aves del Departamento la Paz (Entre Ríos, Argentina). I No Passeriformes. Historia Natural, 8(1), 53-56.

Berduc, A. 1997. Variación latitudinal de los ensambles de aves en la selva de ribera del Parana medio. BSc Thesis. Córdoba: Universidad Nacional de Córdoba. 68pp.

Berduc, A., P.L. Bierig, A.V. Donello \& C.H. Walker. 2010. Lista actualizada y análisis preliminar del uso de hábitat de medianos y grandes mamíferos en un área natural protegida del Espinal con invasión de leñosas exóticas, Entre Ríos, Argentina. FABICIB, 14(1), 9-27.

Berduc, A., R.E. Lorenzón, \& A.H. Beltzer. 2015. Patrones de diversidad de aves a lo largo de un gradiente latitudinal de bosques ribereños del río Paraná medio, Argentina. Revista Mexicana de Biodiversidad, 86(2), 419-430.

Bibby, C.J., N.D. Burgess, D.A. Hill \& S.H. Mustoe. 2000. Bird Census Techniques 2 nd edition. London: Academic Press.

Bini, L.M., J.A.F. Diniz-Filho, T.F. Rangel, R.P. Bastos \& M.P. Pinto. 2006. Challenging Wallacean and Linnean shortfalls: knowledge gradients and conservation planning in a biodiversity hotspot. Diversity and Distributions, 12(5), 475-482.

Birdlife International. 2017a. Important Bird Areas factsheet: Selva de Montiel. http://datazone.birdlife.org/site/factsheet/selva-de-montiel-iba-argentina (access on 11 September 2017).

Birdlife International. 2017b. IUCN Red List for birds. Species factsheet. http://www.birdlife.org (access on 11 September 2017).

Bodrati, A. \& E. Sierra. 2009. Nuevos aportes sobre la colonización austral del Pepitero Verdoso (Saltator similis) en las provincias de Buenos Aires y Entre
Ríos, Argentina. Nuestras Aves, 53, 29-30.

Brown, A., U. Martinez Ortiz, M. Acerbi \& J. Corcuera. 2005. La Situación Ambiental Argentina. Buenos Aires: Fundación Vida Silvestre Argentina. 587pp.

Cantador, P. 2014. Primer registro de Burrito Pico Rojo (Neocrex erythrops) para la provincia de Entre Ríos. EcoRegistros Revista, 4(1), 1-3.

Caprotti, H. 2016. Tachurí Canela (Polystictus pectoralis). http://www.ecoregistros.org/site/imagen. php?id=136507 (access on 7 February 2018).

Casañas, H.E., I. Roesler \& J. Klavins. 2007. Historia natural y distribución de la Cachirla Trinadora (Anthus chacoensis). El Hornero, 22(1), 59-63.

eBird. 2012. eBird: an online database of bird distribution and abundance. http://www.ebird.org (access on 7 February 2018).

de la Peña, M.R. 1997. Lista y distribución de las aves de Santa Fe y Entre Ríos. L.O.L.A. 244 pp.

de la Peña, M.R. 1996. Nuevos registros o aves poco citadas para las provincias de Santa Fe y Entre Ríos, Argentina. El Hornero, 14(3), 87-89.

de la Peña, M.R. 2012. Distribución y citas de aves de Entre Ríos. Serie Naturaleza y Conservación № 6, 1-206.

de la Peña, M.R., \& M. Rumboll. 1998. Birds of Southern South America and Antarctica. Harper Collins Publishers, London, 304 pp.

de la Peña, M.R., R. Laenen Silva, G. Capuccio \& L.M. Bonin. 2009. Aves del Río Uruguay, guía ilustrada de las especies del bajo Rio Uruguay y el embalse de Salto Grande. Montevideo: Comisión Administradora del Río Uruguay. (Unpublished). $247 \mathrm{pp}$.

del Hoyo, J. \& N. Collar 2018. Swainson's Thrush (Catharus swainsoni) HBW Alive. Handbook of the Birds of the World Alive. http://www.hbw.com/species/swainsons-thrush-catharus-swainsoni (access on 16 February 2018).

Fandiño, B. \& A.R. Giraudo. 2012. Un analisis biogeográfico de la composición y distribución de la avifauna de Santa Fe, Argentina. Ornitologia Neotropical, 23(4), 467-488.

Fraga, R.M. 2008. Invalid specimen records of Saffroncowled Blackbird Xanthopsar flavus from Argentina and Paraguay. Bulletin of the British Ornithologist Club, 128, 36-37.

Freiberg, M.A. 1943. Enumeración sistemática de las aves de Entre Ríos. Memorias del Museo de Entre Ríos, 21(1), 1-110.

Giarla, T.C. \& S.A. Jansa 2014. The role of physical geography and habitat type in shaping the biogeographical history of a recent radiation of Neotropical marsupials (Thylamys: Didelphidae). Journal of Biogeography, 41(8), 1547-1558.

Grassini, C.M. 2013. Lechuzón Orejudo (Asio clamator). EcoRegistros. http://www.ecoregistros.org/site/ audio.php?id=959 (access on 7 February 2018).

Grassini, C.M. \& G.H. Bonomi. 2013. Registros del Milano chico (Gampsonyx swainsonii) en el noreste de Entre Ríos, Argentina. Nuestras Aves, 58(1), 3-5.

Holt, D.W., R. Berkley, C. Deppe, P. Enríquez Rocha, J.L. Petersen, J.L. Rangel Salazar, K.P. Segars, 
K.L. Wood \& J.S. Marks. 2018. Austral Pygmyowl (Glaucidium nana). In: del Hoyo, J., Elliott, A., Sargatal, J., Christie, D.A. \& de Juana, E. (eds.). Handbook of the Birds of the World Alive. Lynx Edicions, Barcelona. http://www.hbw.com/ node/55078 (access on 19 February 2018).

Marateo, G., H. Povedano \& J. Alonso. 2009. Inventario de las aves del Parque Nacional El Palmar, Argentina. Cotinga, 31(1), 47-60.

Menéndez, J.L. \& S.M. La Rocca. 2007. Primer Inventario Nacional de Bosques Nativos. Segunda etapa: Inventario de campo de la Región del Espinal, Distritos Caldén y Nandubay. Buenos Aires: Secretaría de Ambiente y Desarrollo Sustentable (SAyDS) de la Nación.

Ministerio de Ambiente y Desarrollo Sustentable \& Aves Argentinas. 2017. Categorizacion de las aves de la Argentina. Ministerio de Ambiente y Desarrollo Sustentable \& Aves Argentinas, Buenos Aires, Argentina. 147 pp.

Morello, J. H., S.D. Matteucci, A.F.S. Rodríguez, A.F. Rodriguez, M. Silva \& A.F.S. Rodríguez 2012. Ecorregiones y complejos ecosistémicos argentinos. 2012 Buenos Aires: FADU. 719 pp.

Myers, N., R.A. Mittermeier, C.G. Mittermeier, G.A.B. Da Fonseca \& J. Kent. 2000. Biodiversity hotspots for conservation priorities. Nature 403(6772), 853858.

Narosky, S. \& D.Yzurieta. 2010. Birds of Argentina \& Uruguay: a field guide. Buenos Aires: Vazquez Mazzini. 427 pp.

Navarro, M.E. 2016a. Bandurria Boreal (Theristicus caudatus). EcoRegistros. http://www.ecoregistros. org/site/index.php (access on 7 February 2018).

Navarro, M.E. 2016b. Pato Crestudo (Sarkidiornis melanotos). EcoRegistros. http://www.ecoregistros.org/site/registro.php?id $=461004$ (access on 7 February 2018).

Nores, M., M.M. Cerana \& D.A. Serra. 2005. Dispersal of forest birds and trees along the Uruguay River in southern South America. Diversity and Distributions, 11(3), 205-217.

Norling, W., C.W. Jeske, T. F. Thigpen \& P.C. Chadwick. 2012. Estimating Shorebird Populations During Spring Stopover in Rice Fields of the Louisiana and Texas Gulf Coastal Plain. Waterbirds, 35(3), 361-370.

Norris, K. \& D.J. Pain. 2002. Conserving bird biodiversity: general principles and their application. Cambridge: Cambridge University Press.

Olrog, C.C. 1968. Las Aves Sudamericanas: una guia de Campo: tomo Primero (Pingüinos-Pájaros Carpinteros). San Miguel de Tutumán: Fundacion Miguel Lillo. 508 pp.

Olrog, C.C. 1979. Nueva lista de la avifauna argentina. Opera Lilloana, 27(1), 1-324.

Ortiz, D. 2008. Distribución Histórica y Actual del Cardenal Amarillo (Gubernatrix cristata) en el Litoral Fluvial Argentino. Insugeo, Miscelánea, 17(1), 121-126.

Parera, A. 1990. Zorzalito migrador (Catharus ustulatus) en Entre Ríos. Nuestras Aves 22(1), 31.

Passafaro, S. 2012. Primeros registros de Saíra dorada
(Hemithraupis guira) para la provincia de Entre Ríos. EcoRegistros Revista, 2(1), 1-3.

Reales, C.F., L. Prevedel, G. Savor \& S. Tessore. 2015. Primeros registros del Cerquero de Collar (Arremon flavirostris) en la provincia de Entre Ríos, Argentina. EcoRegistros Revista, 5(1), 12-14. Remsen, J.V., J.I. Areta, C.D. Cadena, S. Clarmaunt, A. Jaramillo, J.F. Pacheco, J.P. Pérez-Emán, B.M. Robbins, F.G. Stiles, D.F. Stotz \& K.J. Zimmer. 2018. A classification of the bird species of South America. http://www.museum.lsu.edu/ Remsen/ SACCBaseline.htm (access on 7 February 2018).

Rodríguez Mata, J., F. Erize \& M. Rumboll 2006. A Field Guide to the Birds of South America: Nonpasserines: from Rheas to Woodpeckers. New York: Harper Collins Publishers. 384 pp.

Rovira, P. \& A.H. Beltzer. 1992. Una nueva especie para la provincia de Entre Ríos, Argentina. Revista de la Asociación de Ciencias Naturales del Litoral, 23(1 y 2), 71-72.

Sarquis, J.A., J. Alonso, A.R. Giraudo, \& A. Berduc. 2017. First records of Calidris canutus Linnaeus, 1758 (Charadriiformes, Scolopacidae) and Trogon surrucura Vieillot, 1817 (Trogoniformes, Trogonidae) for Entre Ríos province (Argentina), and noteworthy reports of other birds in protected areas. Check List, 13(6), 1067-1073.

Savor, G. 2014. Burlisto Castaño (Casiornis rufus). EcoRegistros. Available at http://www.ecoregistros. org/ficha/Casiornis-rufus.

Serié, P. \& C.H. Smyth. 1923. Notas sobre aves de Santa Elena (Entre Ríos). El Hornero, 3(1), 37-55.

Smyth, C. H. 1928. Descripción de una colección de huevos de aves argentinas. El Hornero, 4(2), 1-16.

Thompson, J.J., A.P. Goijman, J.N. Bernardos, N.C. Calamari, S.B. Canavelli, S. Dardanelli, G.I. GavierPizarro \& M.E. Zaccagnini. 2013. Influencia de la agriculturización sobre aves de pastizal en la región central de Argentina, p. 61-84. In G.D. Marino, F. Miñarro, M.E. Zaccagnini \& B. LópezLanús (eds.). Pastizales y sabanas del cono sur de Sudamérica: iniciativas para su conservación en la Argentina. Temas de naturaleza y conservación, Monografía de Aves Argentinas $N^{\circ}$ 9. Buenos Aires: Aves Argentinas/AOP, Fundación Vida Silvestre Argentina e Instituto Nacional de Tecnología Agropecuaria. Buenos Aires, Argentina. 574 pp.

IUCN. 2001. IUCN Red List Categories and Criteria: Version 3.1. IUCN Species Survival Commission. IUCN, Gland, Switzerland and Cambridge, UK.

Zapata, A. 1975. Aves observadas en la proximidad de la confluencia de los ríos Uruguay y Gualeguaychú, provincia de Entre Ríos. El Hornero, 11(4), 291-304.

Doi: 10.22179/REVMACN.20.577

Recibido: 5-III-2018

Aceptado: 16-X-2018 


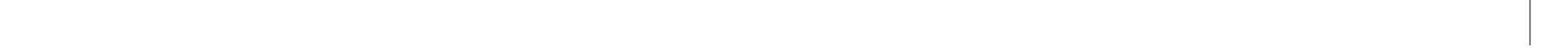

